\title{
Unpublished late period statue, Cairo Museum JE. 36978
}

Dr. Eman Ahmed Abu-Zaid

\begin{abstract}
:
The statue that forms the subject of this paper is in the collection of the Egyptian Museum, (Cairo Museum JE. 36978 ${ }^{(1)}$. This statue dates back to the Late Period and found by Georges Legrain in the Karnak Cachette ${ }^{(2)}$. A full publication of the statue, and the scenes and inscriptions carved on its surface are included here.
\end{abstract}

\section{Keywords:}

Late Period, statues, Karnak, Cachette

- Associate Professor at the Faculty of Archaeology, Egyptology Dept., South Valley University, Qena. Email: eman.abouzaid@arch.svu.edu.eg

${ }^{(1)}$ I am grateful to the Director of the Cairo Museum and to Mr. M. Aly curator of the Late Period Department, for permission to publish the statues herein..

${ }^{(2)}$ PM II, 156 
At $40 \mathrm{~cm}$ in height, the statue depicts the block figure of $N s-b_{3}-$ $n b-\mathrm{D} d^{(3)}$ the son of $P 3-h 3 r-h n s w$ and is made of Granite. The statue is in a fair state of preservation, except for some shattering in its left elbow, represented $N s-b 3-n b-\underline{D} d$ in seated in a squatting position on a low square pillow and completely enveloped by a long cloak. This statue portrays the godfather of Amun in handsome form, completely enveloped by cloak, exposing his crossed-over hands in shallow raised relief on the top surface of the cube which is formed by his folded body. The forearm is carved with the name and the titles of the owner. His hands rest palm-down on the top surface of the cube, lacking wrists and the right hand is holding a folded cloth or papyrus while the other is bearing the ${ }^{2} h h$ sign. Seven horizontal rows of unframed inscription cover the front of the cloak with a vertical line presented on the toes. The back-pillar presented here is in wide form and engraved with two unframed columns descending to the figure of his son that is presented on it. Additional inscriptions of his sons are on each side of the body. All of the inscriptions although completely legible, are somewhat crudely executed.

The owner wears a broad, flat crowned, big wig presenting the well detailed ears exposed. Its rounded ends rest on top of the rectangular back pillar, and reach out to the extremities of the shoulders. The face is square-shaped, with a short section of beard attached to the chin, sinking into the surface of the cube. The smiling-mouth is thick-lipped and narrow. The almondshaped eyes, long cosmetic lines emerging from their outer corners, have plastically rounded upper eyelids, surmounted by elegantly carved eyebrows in raised relief. The nose is broad and well carved flanked by the kushite fold at its nostrils.

\footnotetext{
${ }^{(3)}$ This statue has not been published previously, though it was referred to by Azim, Réveillac, Karnak dans l'objectif de Georges Legrain, paris 2004; K. JansenWinkeln, Biographische und religiöse Inschriften der Spätzeit aus dem Ägyptischen Museum Kairo, ÄAT 45, Wiesbaden, 2001
} 


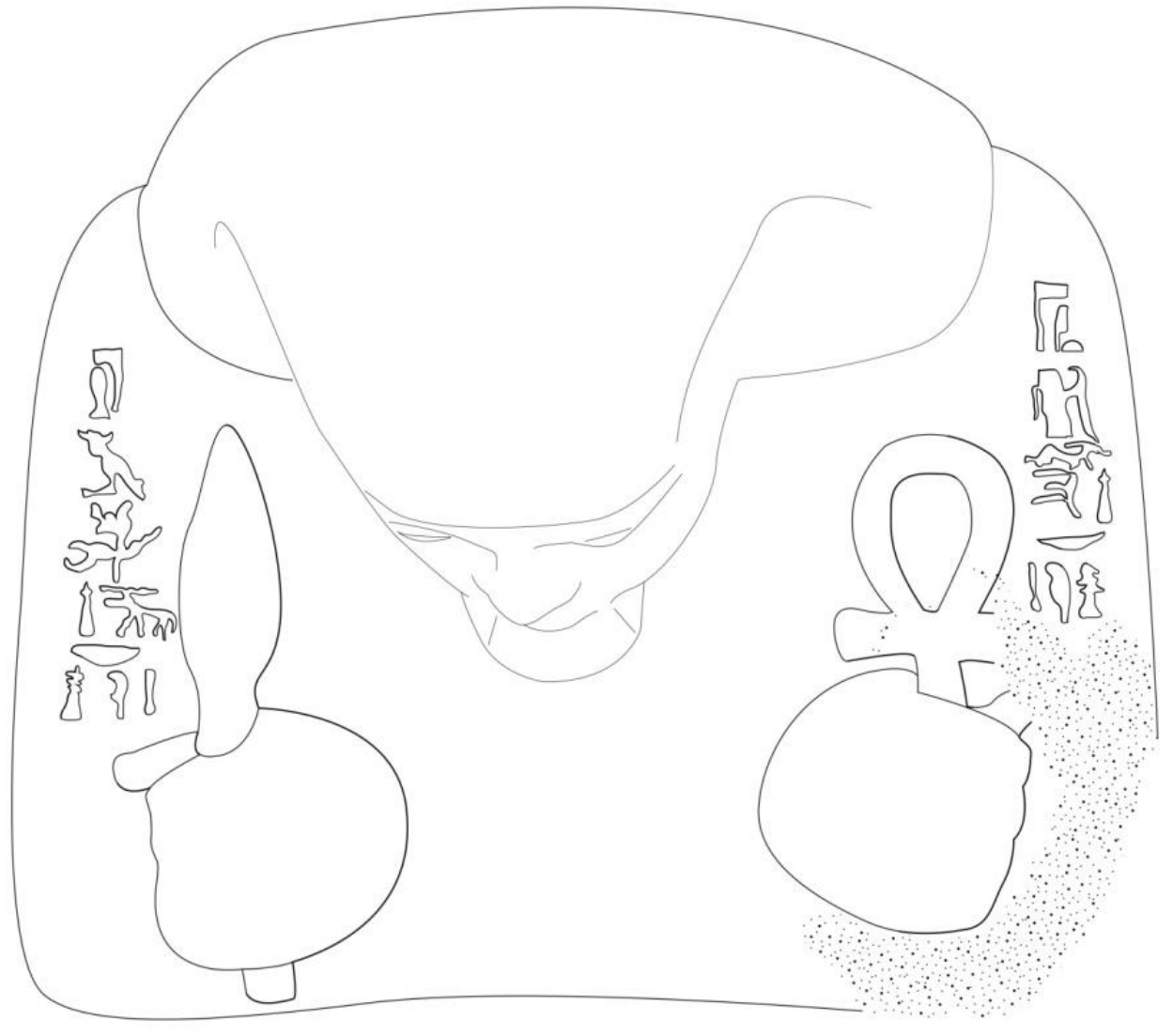

Fig.(1): Facsimiles of the inscriptions on the forearm, by the researcher

\section{The inscriptions}

\section{The forearm: Fig. (1)}

On the right and left forearm of the statue are engraved two lines of inscription in sunken relief, reads 
19

$h m n \underline{t r} m$ srḳ-ḥtyt ${ }^{(\mathrm{a})} n s-b 3-n b-d d^{(\mathrm{b})} m \jmath^{\mathrm{C}} h r w$

The priest who lets the throat breathe $N s-b 3-n b-\underline{d} d$,

原 Justified

善 $\int \delta$

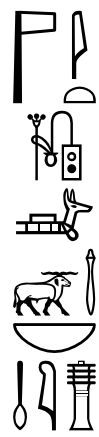

It ntr š̌ bỉ ns-b3-nb-dd $m 3^{\complement}$ hrw

The godfather, the marvelous scribe $N s-b 3-n b-\underline{d} d$, Justified

(a) The earliest attestation of $s r k^{(4)}$ is in Pyr.\$1158, means "to inhale" and when compounded with htyt/ihty ${ }^{(5)}$ can be "to cause the throat to breathe", "to open the throat" (6). From the new kingdom onwards, it is attested as an epithet for many gods, such as Amun-Re, Bhdty, and Osiris ${ }^{(7)}$. The title accompanies the priest $N s-b 3-n b-\underline{d} d$ after his death and takes his Osiris configuration. For other examples of this title during the Late Period, see R. El-Sayed, Documents relatifs à Saïs et ses divinités (BdE 69), 1975, p.12 (n).

(b) PN. I, 174.17

\footnotetext{
${ }^{(4)} W b . I V, 201-203$

${ }^{(5)}$ Wb. IV, 202. 9; LPE, p. 87-88 (I. 6-7)

(6) P.Wilson, OLA 78, 1997, p.887

(7) $L G G$. VI, 434
} 


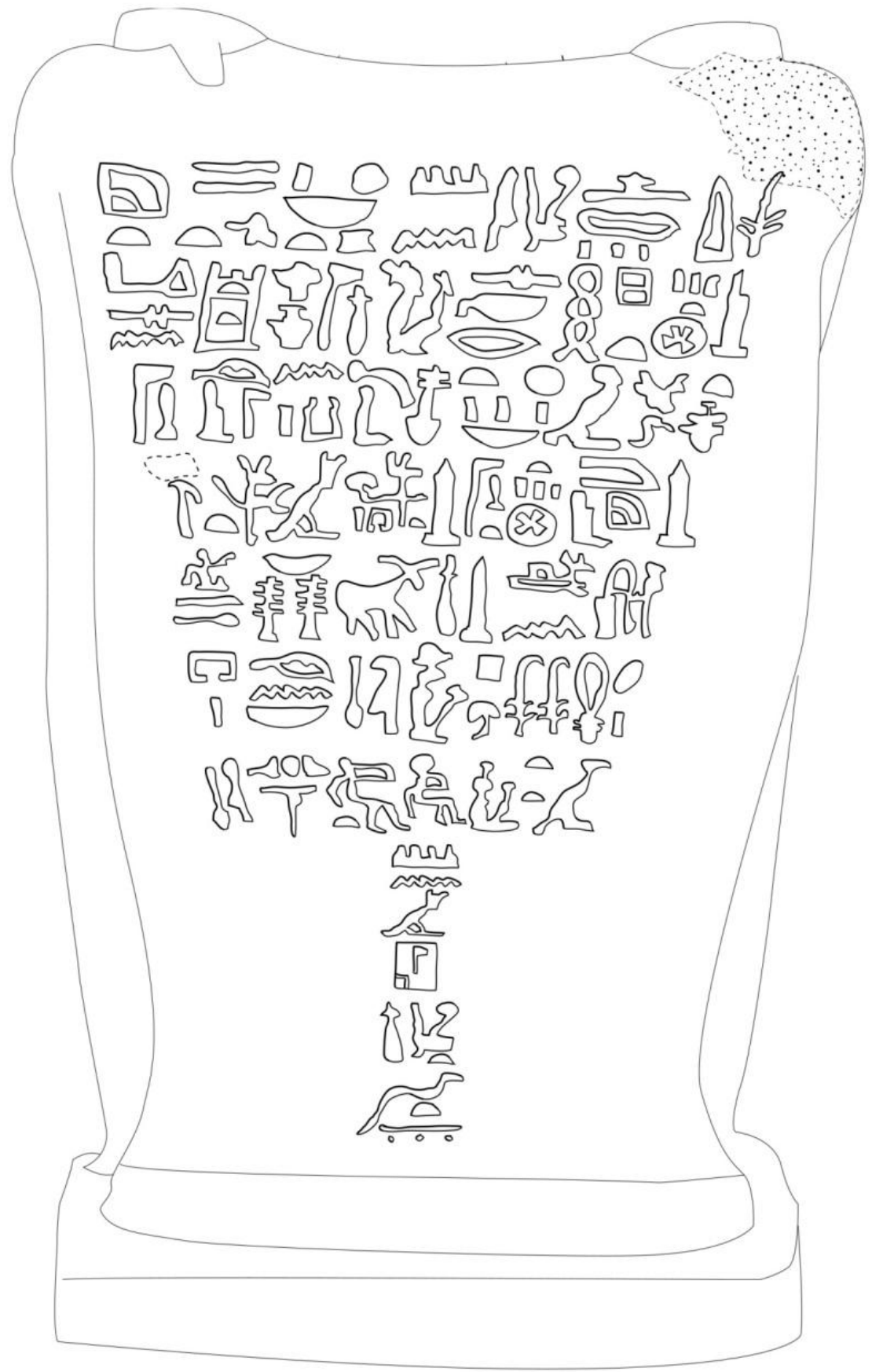

Fig.(2): Facsimiles of the inscriptions on the cloak, by the researcher 


\section{The cloak: Fig. (2)}

The front of the cloak is engraved with unframed seven horizontal lines of inscription and one short vertical line on the toes. All of them are in sinking relief and are somewhat crudely executed.
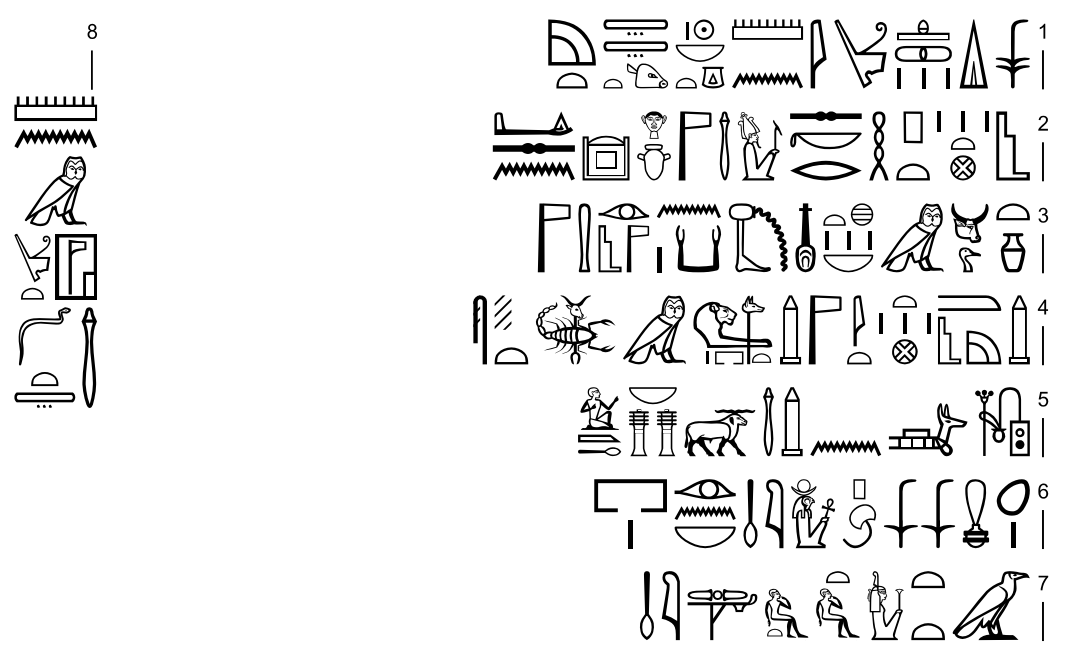

1. htp di nswt n Imn-r ${ }^{\odot}$ b nswt t3wy hnty ipt

2. swt pth skr wsir (a) $n t r r$ e $h r y-i b k r s t t^{(b)}$ di .sn

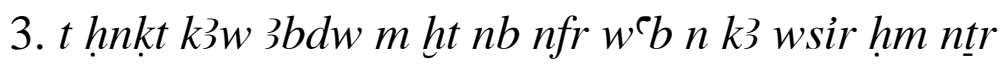

4. imn m ipt-swt it-ntr hạm-ntr ${ }^{(\mathrm{c})} i m n$ wsr-ḥıt ${ }^{(\mathrm{d})} m$ srk-ḥtyt

5. š̌ bỉ n imn $n s-b \jmath-n b-d d^{(\mathrm{e})} m \jmath^{\complement}$ hrww

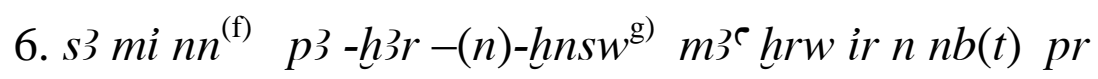

7. 3tt-m3rt-šrit-min ${ }^{(\mathrm{h})} m 3^{\mathrm{C}}$ hrw

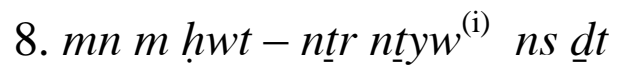

1. An offering that the king gives to Amun-Re, lord of the throne of the land in front of Karnak

2. Ptah, Soker, Osiris, the great god, who resides in the burial that they may give 
3. The bread, Hnket, oxen, fowl, and everything good, pure for the Ka of Osiris, the priest

4. Amun in karnak, the godfather and the priest of Amun wsr-h3t who lets the throat breathe,

5. The marvelous scribe of Amun Ns-b3-nb-dd, Justified

6. The son of the like-titled p3-h3r-hnsw Justified, born of the lady of the house

7. 3tt-m3't-šit-min Justified

8. Established in the temple of the gods, forever and ever, $O$, Nsb3-nb-dd.

(a) The god Osiris is written here in ideogram.

(b) The title hry-ib krst, see LGG. V, 350.

(c) The title it-ntr hm-ntr, presented here in abbreviated writing, also in Cairo museum JE. 37861, JE. 3860, JE.38064 and Metropolitan museum MMA 08.202; Herman De Meulenaere, in $C d E$ 68, 46;48 1, For the title it-ntr, see: L. Habachi, in: $L A$ II, 825-826; s.v.Gottesvater; id., in: ASAE 55, 1958, 167-190; AEO I, 47*; H. Brunner, in: ZAS 86, 90 100; H. Kees, in: ZAS 86, 115125; Mostafa El-Alfi, in: GM 30, 16; Essam El-Banna, in: BIFAO $86,151$.

(d) The title imn $w s r-h 3 t$, see $L G G$. I, 315, for $w s r-h 3 t$ as a name of Amun's bark, see Herman De Meulenaere, in: BIFAO 86, 138.

(e) The name of $n s-b 3-n b-\underline{d} d$ is written in the texts on this statue

in two different forms one time as स्री

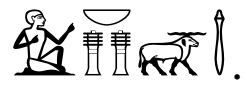

(f) The expression s3 mi nn, see John Gee, in: GM 202, pp.55-58. (g) PN. I, 116.18 
(h) The proper name $3 t t-m 3{ }^{2} t$-šrit-min is not cited in $P N$.

(i) $h w t$ - ntr ntyw $n s \underline{d} t$ is the most likely the correct reading for the question signs after hwt-ntr res? the vertical wooden column is considered as an initial sign of the owner referring to his name.

\section{Back pillar: Fig. (3)}

The engraved back pillar bears two rows of text above which is a scene displaying an engraved figure of the godfather $N s-b 3-n b-\underline{d} d$ son, facing right and wearing a long garment with unclear details as a sash kilt.

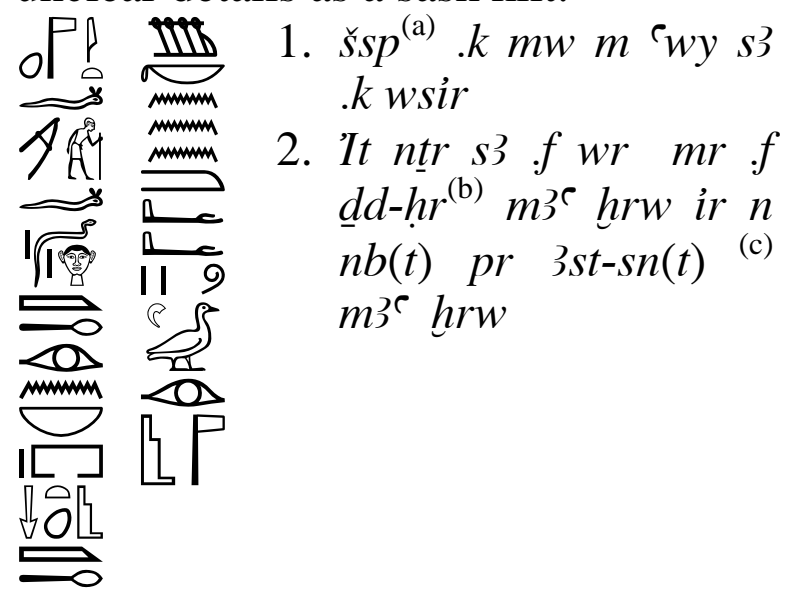

1. May you recive the water from the arms of, your son osiris,

2. The godfather, his son, the great, his beloved $\underline{d} d-H r$, justified, born of the lady of the house 3st-snt, justified.

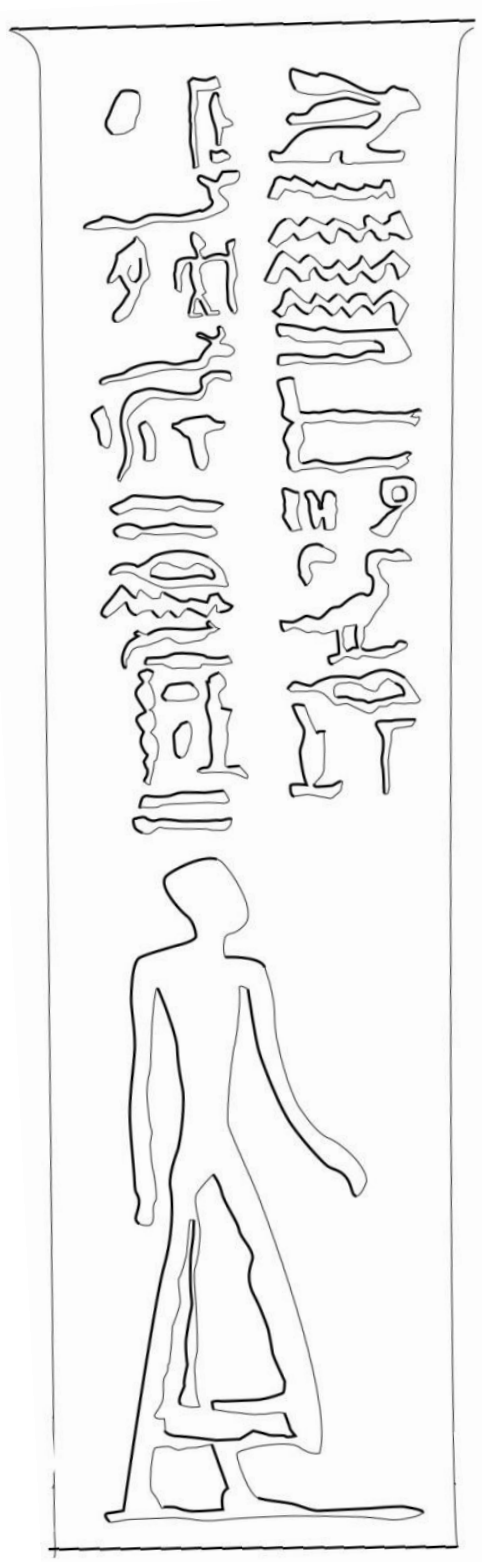

Fig.(3): Facsimiles of the inscriptions on the forearm, by the researcher 


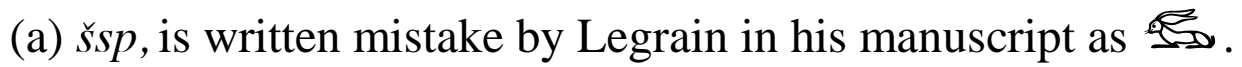

(c) PN. I, 411.12

(d) The proper name $3 s t-s n(t)$ is not cited in $P N$.

\section{The right side: Fig. (4)}

The right side was engraved by the figure of his second son, facing left and wearing a sash kilt, framed by three lines of hieroglyphic inscriptions from three sides, reading as the following:

(a) It is not mentioned in $P N$.

(b) PN. I, 4.1.

(c) The exact reading of these signs is uncertain.

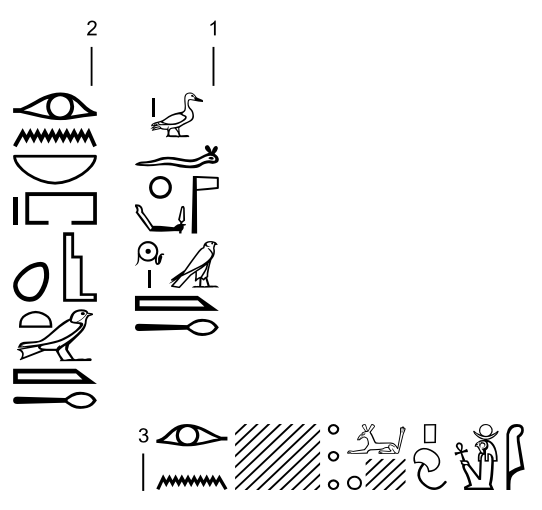

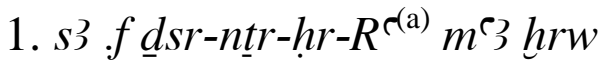
2. ir $n n b(t)$ pr $3 s t w r t^{(\mathrm{b})} m^{\mathrm{e}} 3$ hrw

3. ir $n$....... (c) ${ }^{3} 3-h 3 r-h n s w ~ m 3^{c}$ 1. His son $\underline{d} s r-n \underline{t} r-h \underline{r}-R^{r}$, justified

2. the born of the lady of the house 3st-wrt, justified

3. The born.....P3-h3r-hnsw, justified

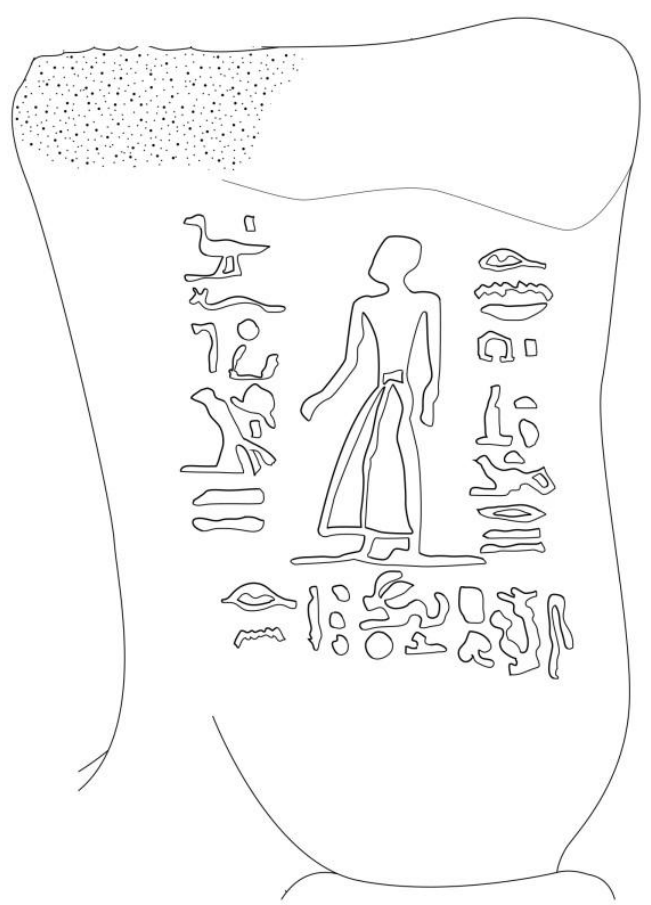

Fig.(4): Facsimiles of the right side, by the researcher 


\section{The Left Side: Fig. (5)}

The scene here presents the engraved figure of the son, also wearing a sash kilt, rounded from three sides by unframed five incased lines of hieroglyphic inscriptions, reading:
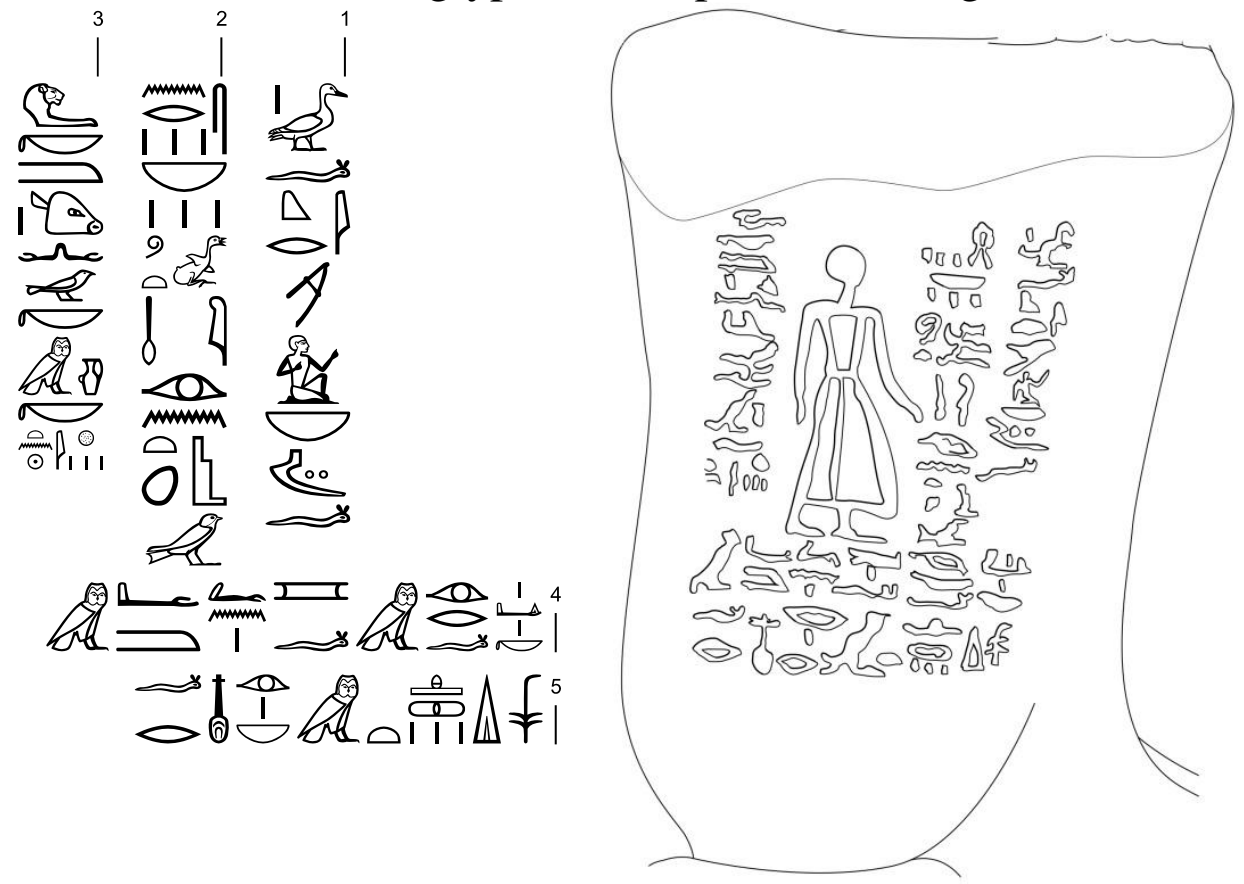

1. s3. fikr mr (ff) $n b m 33 . f$

Fig.(5): Facsimiles of the left

2. snrw-nbw-t3wt ${ }^{(\text {a) }} m 3^{r}$ hrw ir $n$ 3st side, by the researcher $w r(t)$

3. ḩ3ty .k m hnt nn ski . ${ }^{(\mathrm{b})} h n m$.k sp 3 itn

4. di .k ir f $m \mathrm{mr}$.f $r m n^{\mathrm{c}} \mathrm{m}$

5. htp di nswt m ir $n b$ nfr

1. his son, the excellent, his beloved, lord of his sight

2. Snrw-nbw-TAwt, justified, the born of Ast-wr(t)

3. your heart in the front, and not dying, may you unite, may you unite, may you unite, with Atun,

4. you give, and he make what he desire, your arm bear with

5. the offering that the king gives from everything good. 
(a) It is not cited PN.

(b) $s k$ is the antonym of ' $n h$ and refers to utter destruction and death, often parallel in use with htm, see, P. Wilson, OLA 78, 1997, p.941.

Based on the inscriptions described above, the family genealogy of the statue owner is as follows:

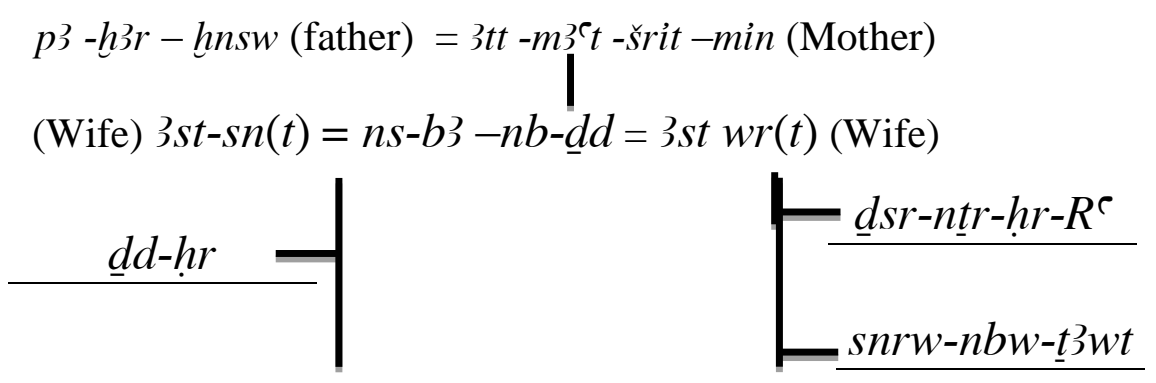

\section{Commentary}

There are two basic types of block statues, both of which were created as early as the Middle Kingdom. One shows the subject entirely wrapped in the cloak; only the hands and the head protrude, while the feet are covered. The second type has the feet uncovered, and the arms are either modeled freely three-quarters in the round or are wrapped in the cloak ${ }^{(8)}$. Only the first of these two types is of interest here. It is by far the most typical form of the block statue in the Late Period, the head of the sculpture shown here looks alert, presumably a well-calculated effect, which could not fail to attract the visitor to the temple of Karnak, where, in the presence of his gods, the man represented wished to be remembered forever ${ }^{(9)}$. His name, as we learn from the inscriptions, was $N s-b 3-n b-\underline{d} d$. He was a Theban priest and god father of Amun. This portrait of the Theban priest shows the classic figure of a striding man of powerful build and ideal

\footnotetext{
${ }^{(8)}$ Vandier, Manuel III, pp. 235-237.

${ }^{(9)}$ B. V. Bothmer, ESLP., 1960, 5
} 
proportions in the best Egyptian tradition. The extremely hard material has been treated with great ease.

Several philological peculiarities of the inscriptions point to the Late Period, especially $P$ for the suffix pronoun of the second person $^{(10)}$, and the name of the father $p 3-h 3 r-h n s w$ which occurs frequently in Late to Ptolemaic period ${ }^{(11)}$.

The wide wig of this man obviously points to early Saite date; its less flaring shape is characteristic for the sixth century. Thick plastic eyebrows and the nearly total absence of cosmetic lines at the corners of the narrow eyes occur often under Psamtik II and Apries $^{(12)}$. On the other hand, the treatment of eyebrows and eyes is still found under Apries. The notches at the corners of the mouth, already noted earlier, are in this head particularly noticeable. These triangular depressions are among the many features of Egyptian modeling which were taken over directly by the Greek sculptors of the Archaic Period.

\footnotetext{
$\left({ }^{10}\right) W b . V, 83$

(11) Hassan Selim, "Three Unpublished Late Period Statues", SAK 32, 2004, p. 363-378

${ }^{(12)}$ B. V. Bothmer, op.cit., 53
} 


\section{References}

Azim, Réveillac, Karnak dans l'objectif de Georges Legrain, paris 2004 Bertha Porter and Rosalind L. B. Moss, Topographical bibliography of ancient Egyptian hieroglyphic texts, statues, reliefs and paintings, Oxford: Griffith Institute, 2012

Bothmer, Bernard, Egyptian Sculpture of the Late Period, 700 B. C. to A. D. 100, Brussels: Fondation égyptologique Reine Elisabeth, 1960-1971

Essam El-Banna, "À propos de la désignation "père des dieux ([...], [it netjerou])", BIFAO 86, 1987

H. Brunner, "Der Gottesvater" als Erzieher des Kronprinzen”, Z $\ddot{A} S$ 86, 1961

H. Kees, "Gottesväter” als Priesterklasse”, ZÄS 86, 1961

Hassan Selim, "Three Unpublished Late Period Statues”, SAK 32, 2004

Herman De Meulenaere, "Une famille sacerdotale thébaine. [I. - Karnak, Karakol 69 + Caire JE 51897. II. - Caire JE 36663. III. - Amsterdam, Allard Pierson Museum B 8844”, BIFAO 86, 1987.

Hermann Ranke, Die ägyptischen Personennamen. Bd I. Verzeichnis der Namen, Glückstadt: J. J. Augustin, 1935

J. Vandier, Manuel d'archéologie égyptienne. Tome VI. Bas-reliefs et peintures. Scènes de la vie agricole à l'Ancien et au Moyen Empire, Paris: Éditions A. et J. Picard et Cie, 1978

John Gee, “s3 mi nn: A Temporary Conclusion", GM 202, 2004

K. Jansen-Winkeln, Biographische und religiöse Inschriften der Spätzeit aus dem Ägyptischen Museum Kairo, $\ddot{A} A T$ 45, Wiesbaden 2001

L. Habachi, " Gottesvater”, LA II, 825

Leitz, Christian, Lexikon der ägyptischen Götter und Götterbezeichnungen. 7 vols. OLA, voles. 110-16. Leuven: Uitgevertij Peeters 2002

Mostafa El-Alfi, "Two Egyptian Statuettes in the Museum of Cherchel in Algeria”, GM 30, 1978

R. El-Sayed, "Documents relatifs à Saïs et ses divinités", BdE 69, 1975 Wilson, Penelope, A Ptolemaic Lexikon : A Lexicographical Study of the Texts in the Temple of Edfu, Leuven : Peeters, 1997 


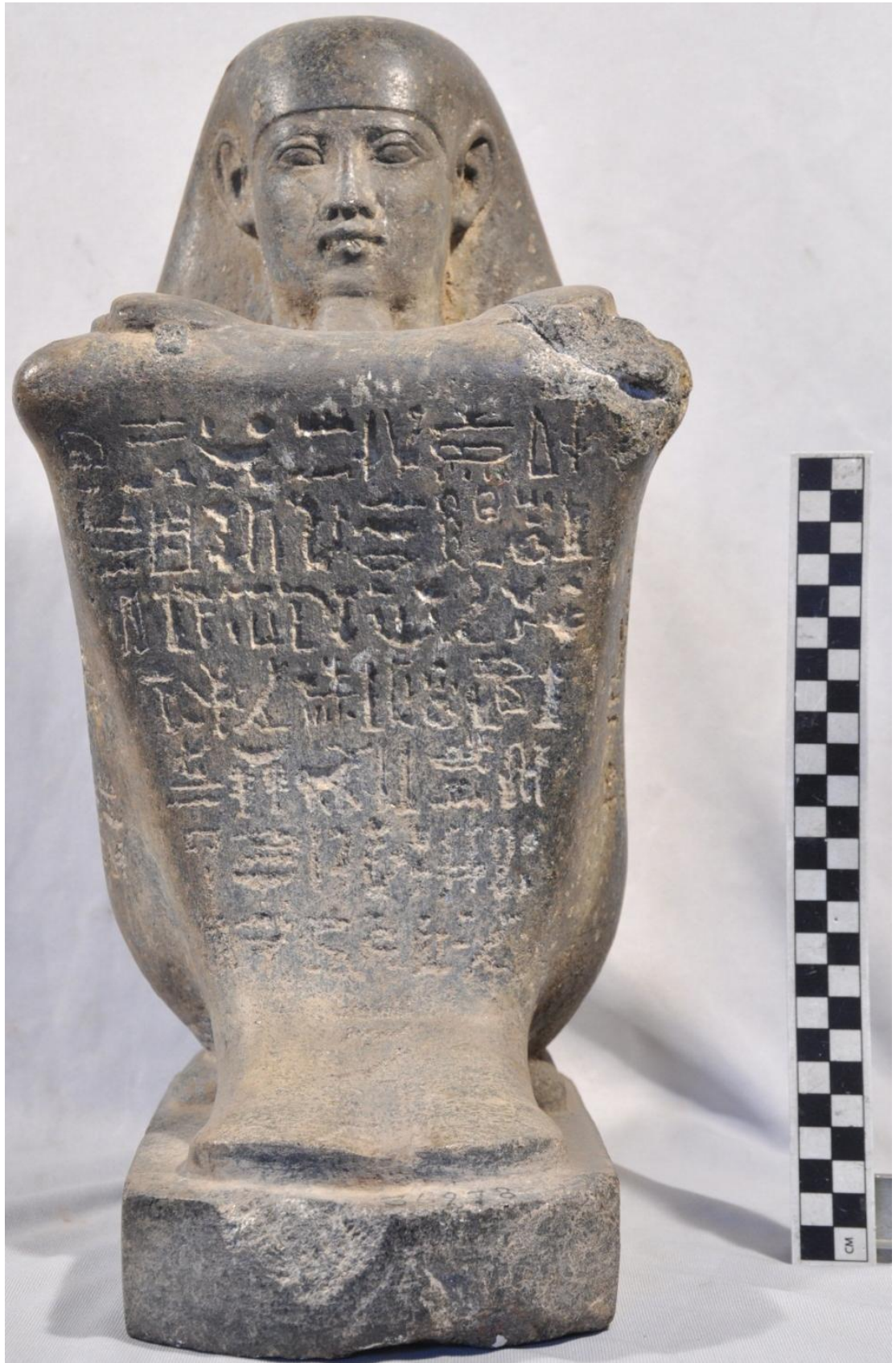

Fig.(6): The block statue Cairo Museum JE. 36978

${ }^{(13)}$ The photos here are taken by the researcher himself from the Egyptian museum. 

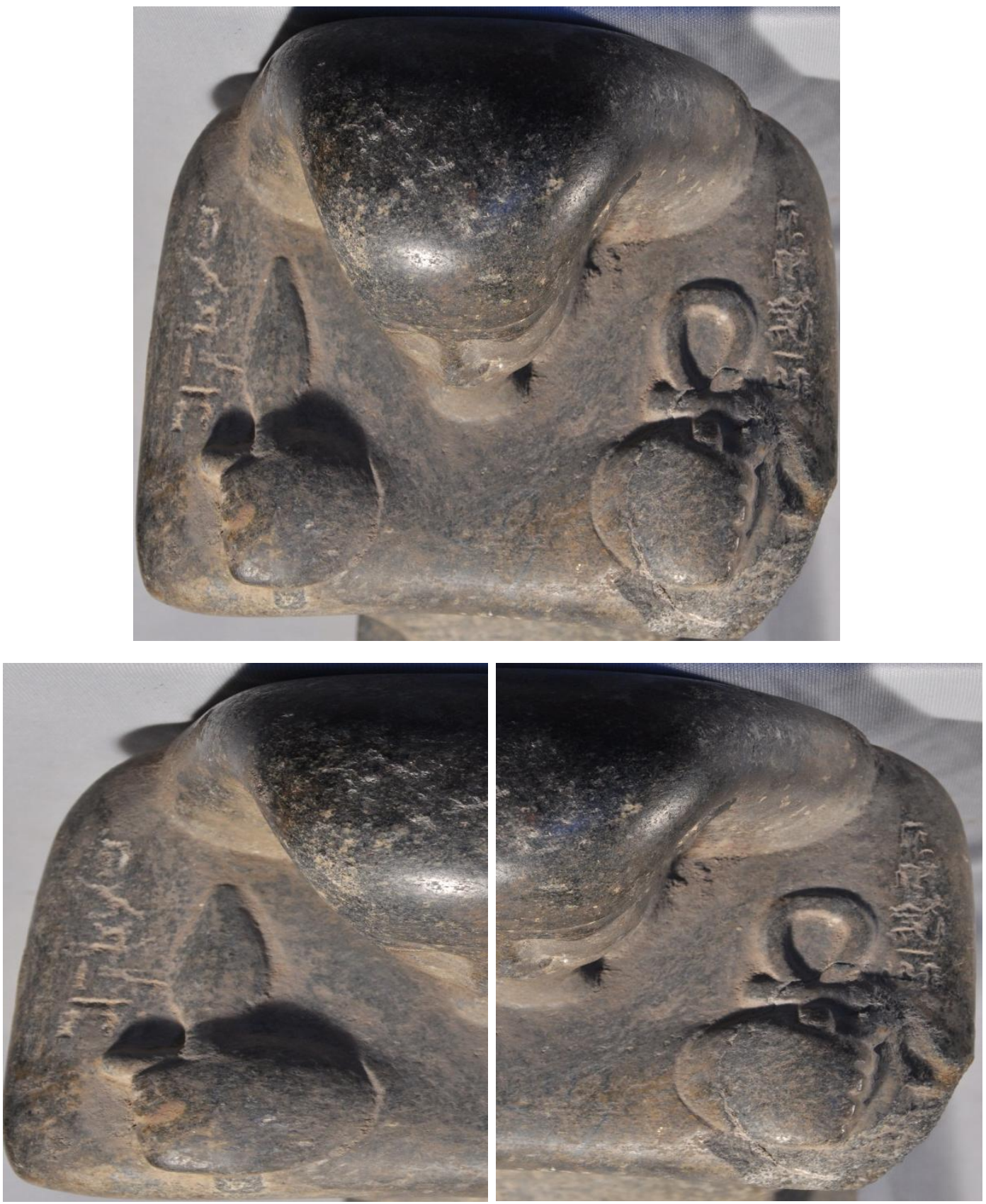

Fig.(7): The forehead of the block statue Cairo Museum JE. 36978 


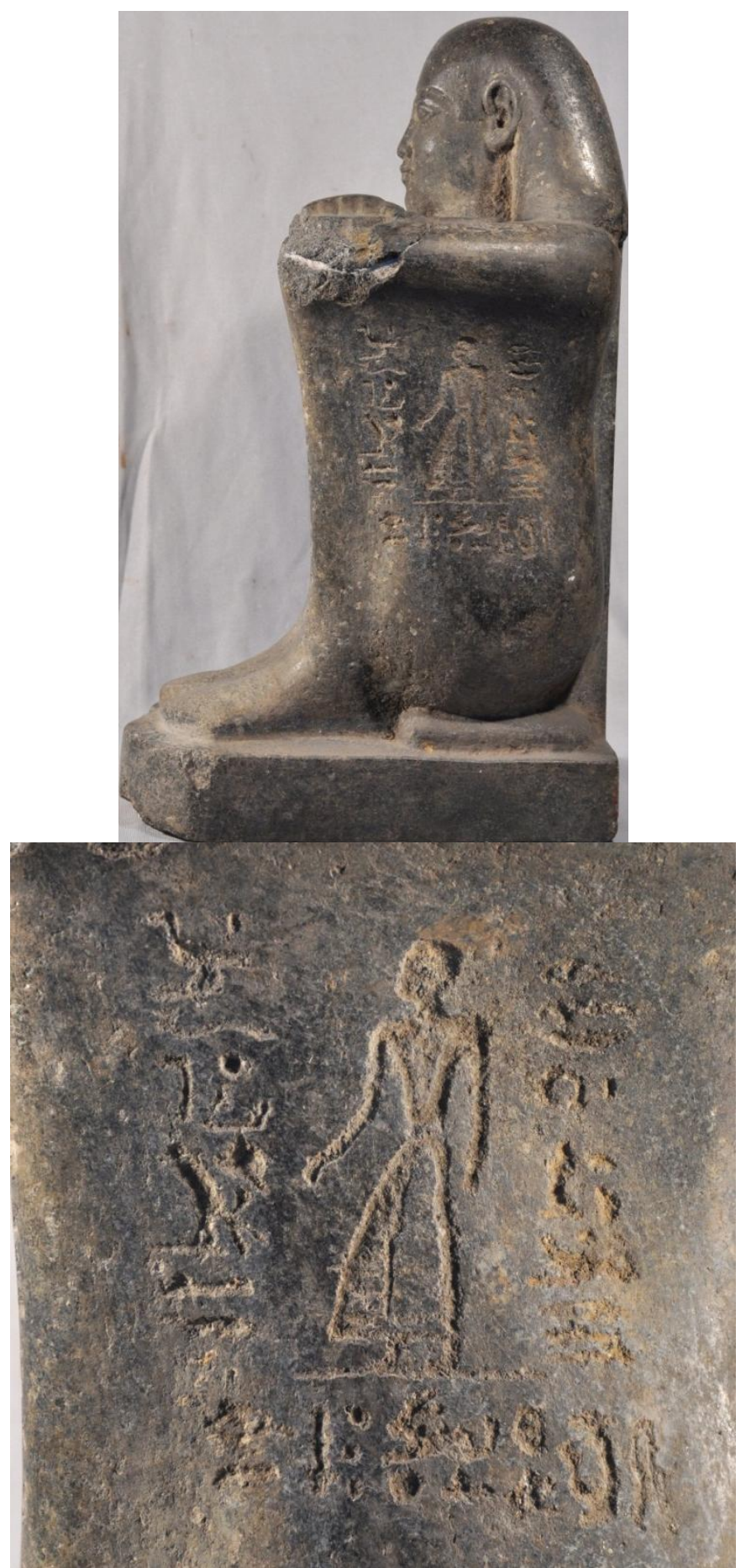

Fig.(8): The right side of the block statue Cairo Museum JE. 36978 

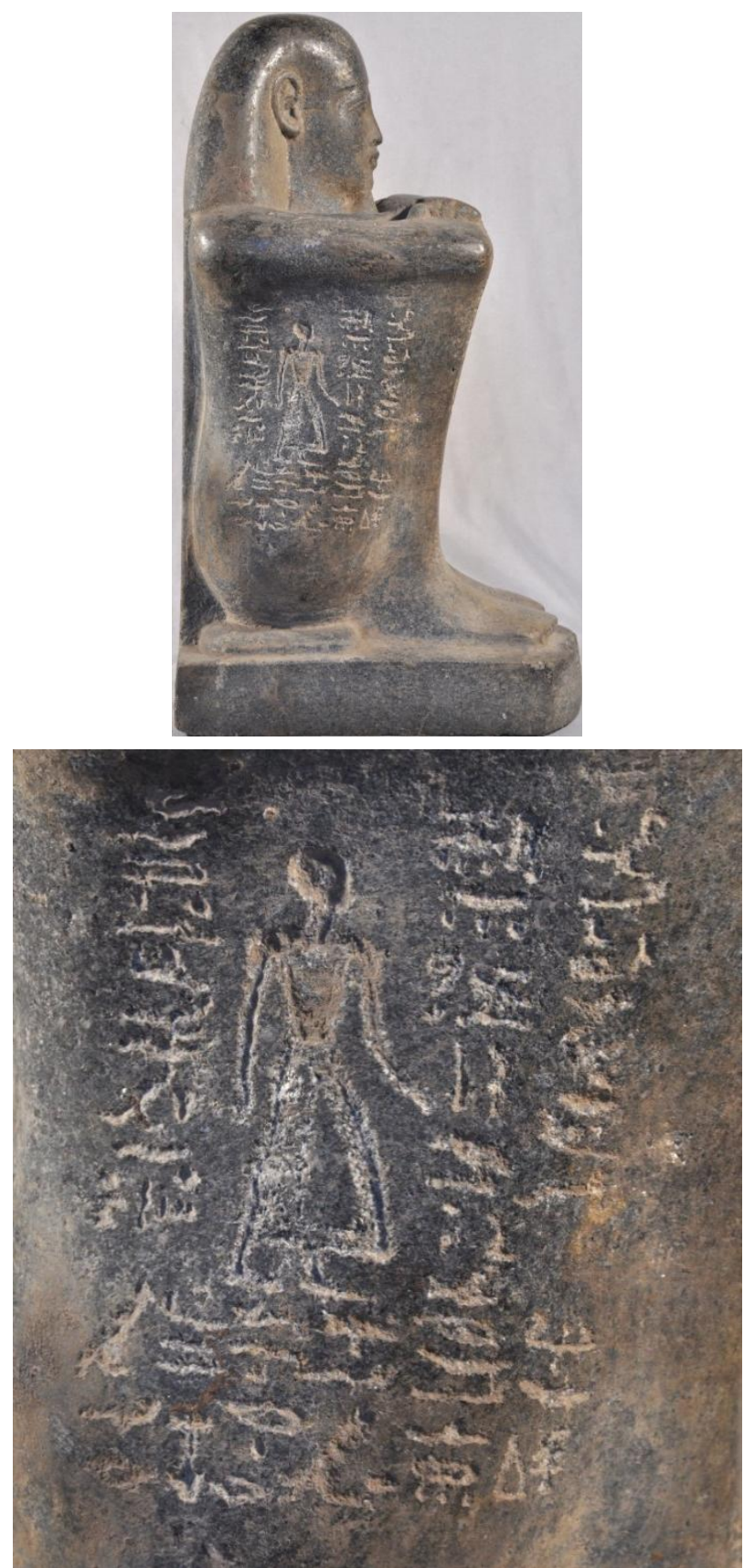

Fig.(9): The left side of the block statue Cairo Museum JE. 36978 


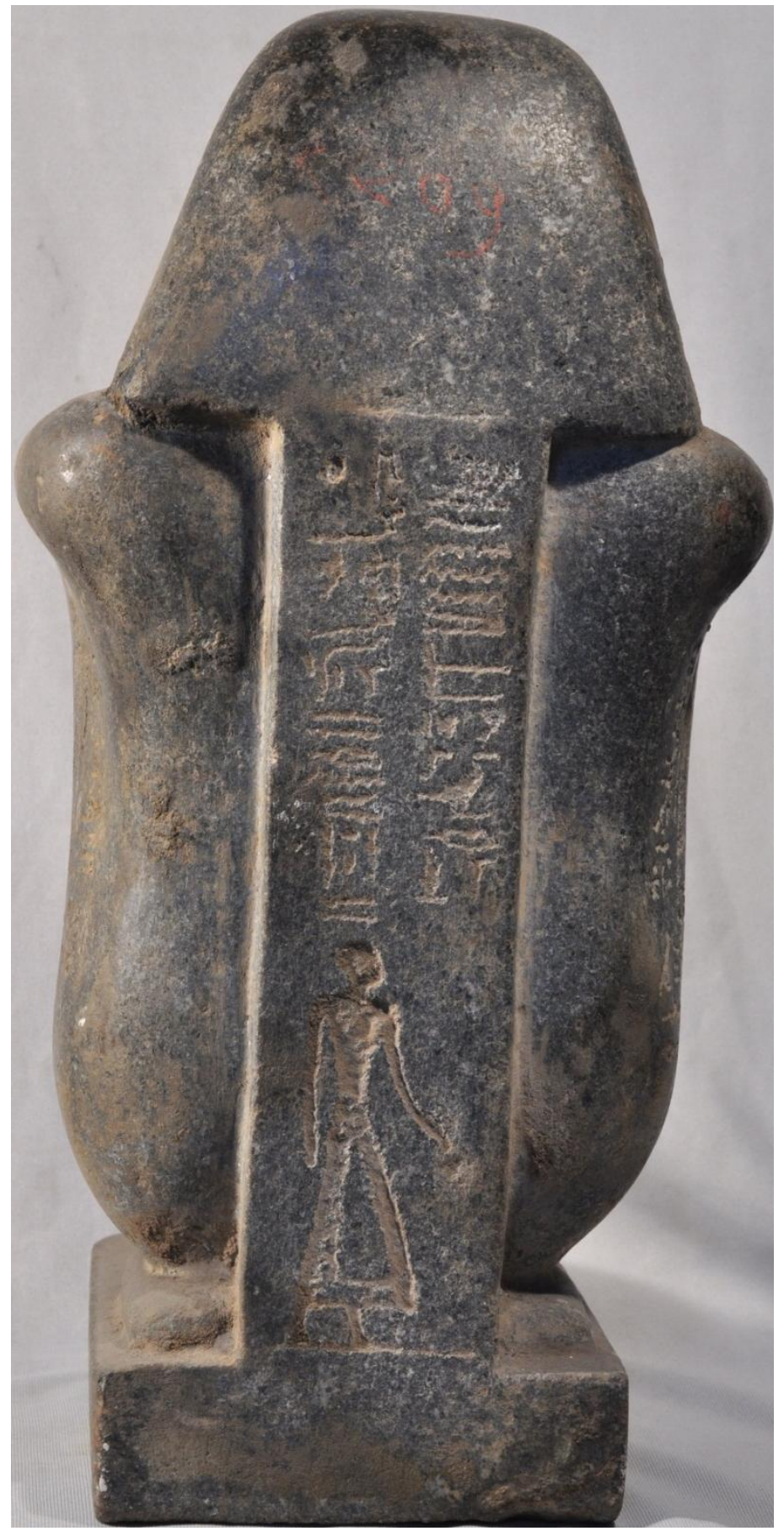

Fig.(10): The back pillar of the block statue Cairo Museum JE. 36978 
تمثال يعود الي العصر المتأخر غير منشور بالمتحف المصري بالقاهرة رقم

\section{د.ايمان احمد ابوزيد}

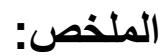

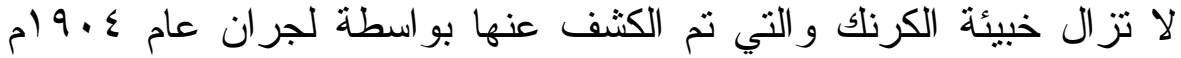

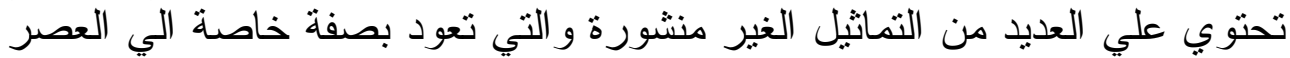

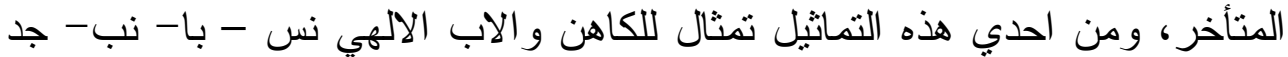

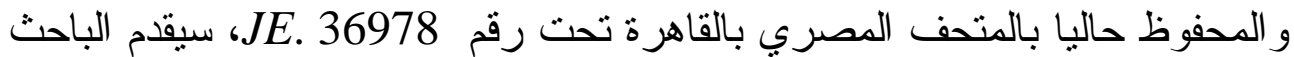
در اسة تحليلية للنصوص واليا بالحناظر المسجلة علي جو انب التمثال.

الكلمات المفتاحية:

خبيئة الكرنك - العصر المتأخر - المتحف المصري 